\title{
Effect of recycling wood ash on microbiological and biochemical properties of soils
}

\author{
Piero PeRUCCI, Elga Monaci, Cristiano CASUCCI*, Costantino VischetTI
}

\author{
Dipartimento di Scienze Ambientali e delle Produzioni Vegetali, Università Politecnica delle Marche, Via Brecce Bianche, 60131 Ancona, Italy
}

(Accepted 23 May 2006)

\begin{abstract}
Wood ash production is increasing due to the increasing use of wood as a sustainable fuel. Wood ash can be recycled in crop soils as a source of nutrients and as a liming agent to correct soil acidity. However, the effect of wood ash on soil quality is poorly known. Here we studied the effect of addition of wood ash at 5 and $20 \mathrm{t} \mathrm{ha}^{-1}$ on microbial and biochemical properties in samples from the $0-30 \mathrm{~cm}$ surface of three neutral and two alkaline agricultural soils. The samples were incubated for one year at $25{ }^{\circ} \mathrm{C}$ and $60 \%$ water-holding capacity. The soil microbiological biomass (microbial biomass $\mathrm{C}$ and $\mathrm{N}$ ), general microbial activity using fluorescein diacetate hydrolysis, and alkaline phosphatase, arylsulphatase, catalase and $o$-diphenoloxidase activities were determined periodically together with $\mathrm{pH}$ and electrical conductivity. Increases in microbial biomass $\mathrm{C}$ and fluorescein diacetate hydrolysis occurred at the lower wood-ash dose, whereas microbial biomass $\mathrm{C}$ decreased at the higher wood-ash dose over the entire period, and the fluorescein diacetate hydrolysis after 4 months. The microbial C/N ratios of treated samples were significantly different with respect to that of the control, suggesting changes in the structure of the microbial communities. The changes in microbial biomass and microbial activity were related to the increases in $\mathrm{pH}$, which induce the development of bacteria to the detriment of fungi, to the electrical conductivity, and to the nutrient levels after wood-ash addition. Alkaline phosphatase and arylsulphatase activities were weakly inhibited at $20 \mathrm{t} \mathrm{ha}^{-1}$, and catalase activity was stimulated in the neutral samples and inhibited in the alkaline samples. The highest $o$-diphenoloxidase activity observed throughout in all of the treated samples may suggest a decrease in the mineralisation process. Our findings reveal that the soil biochemical parameters investigated are significantly affected only in some cases at $20 \mathrm{t} \mathrm{ha}^{-1}$, suggesting that a treatment exceeding $5 \mathrm{t} \mathrm{ha}^{-1}$ is not recommended until the agro-chemical and physical functions of the soil are further studied.
\end{abstract}

wood ash / enzyme activities / FDA hydrolysis / microbial biomass / C/N biomass ratios

\section{INTRODUCTION}

Wood ash (WA) is increasingly being produced as a consequence of the increased use of wood as an energy-supply source. Generally these wastes are disposed of in landfill sites or lagoons (Vance, 1996) or used in brickworks. However, the increasing costs of these materials and the difficulties of acquiring new landfill sites have encouraged the search for alternative methods of disposal.

A number of studies have been carried out on the utilisation of WA either for correcting nutrient deficiencies or imbalances due to acid deposition and leaching in forestry soils (Cronan and Grical, 1995), or as a liming agent in agricultural soils. Application to soil is a convenient way of recycling some nutrients, such as $\mathrm{Ca}, \mathrm{K}, \mathrm{Mg}$, $\mathrm{Na}$ and $\mathrm{P} ; \mathrm{N}$ and $\mathrm{S}$ are absent or generally present in WA at low concentrations, due to their volatilisation during combustion (Vance and Mitchell, 2000).

Little is known, however, of the effects of WA application on the physical and mineralogical properties of soil, and on the microbial biomass and enzyme activities in boreal forests (Buttner et al., 1998; Giller et al., 1998), where precipitation far exceeds evapotranspiration and the soils are generally podsolised. WA is essentially composed of fine particles that swell when they come into contact with water, with obstruction of soil pores; thus, WA can affect the texture, aeration, waterholding capacity, salinity and hydraulic conductivity of soil.

High application rates of WA can add to the soil not only a large quantity of nutritive elements but also a moderate quantity of heavy metals in more- or less-available forms. This could negatively affect microbial activity and thus the mineralisation of organic matter with a consequent accumulation of soil organic matter. Berg et al. (1991) demonstrated a reduction in the decomposition rates of the organic matter in Scots pine needle litter under metal pollution.

Few studies have been carried out on WA recycling and its influence on the microbial biomass and enzyme activities of soils different from boreal forest soils (Demeyer et al., 2001; Perkiomaki and Fritze, 2002; Zimmermann and Frey, 2002). The present study was carried out under laboratory conditions to determine the effects of WA addition on physico-chemical, microbial and biochemical properties of neutral and alkaline agricultural soils, which are typical of the Mediterranean area.

* Corresponding author: c.casucci@univpm.it 
Table I. Soil and wood ash properties.

\begin{tabular}{|c|c|c|c|c|c|c|}
\hline & $\mathrm{S} 1 *$ & $\mathrm{~S} 2 *$ & $\mathrm{~S} 3 *$ & S4* & S5* & WA \\
\hline Skeleton (\%) & nd & nd & 10 & 30 & nd & - \\
\hline Sand $(\%)$ & 26 & 49 & 63 & 68 & 23 & - \\
\hline Silt $(\%)$ & 20 & 38 & 23 & 13 & 40 & - \\
\hline Clay $(\%)$ & 55 & 23 & 14 & 20 & 37 & - \\
\hline $\mathrm{pH}\left(\mathrm{H}_{2} \mathrm{O}\right)$ & 8.1 & 6.3 & 6.6 & 6.7 & 8.3 & - \\
\hline $\mathrm{CaCO}_{3}(\%)$ & 5.0 & - & - & - & 24 & 22 \\
\hline $\mathrm{P}_{\text {total }}\left(\mathrm{mg} 100 \mathrm{~g}^{-1}\right)$ & 75 & 66 & 75 & 114 & 155 & 300 \\
\hline $\mathrm{K}_{\text {total }}\left(\mathrm{mg} 100 \mathrm{~g}^{-1}\right)$ & 31 & 6 & 10 & 3 & 27 & 3500 \\
\hline Organic matter $(\%)$ & 1.77 & 2.76 & 2.13 & 2.33 & 1.72 & - \\
\hline C.E.C. $\left(\right.$ meq $\left.100 \mathrm{~g}^{-1}\right)$ & 10.37 & 14.03 & 7.93 & 21.96 & 26.70 & - \\
\hline $\mathrm{EC}\left(\mu \mathrm{S} \mathrm{cm}{ }^{-1}\right)$ & 678 & 815 & 1045 & 744 & 624 & - \\
\hline $\mathrm{Cu}\left(\mathrm{mg} \mathrm{kg}^{-1}\right)$ & 32 & 20 & 17 & 16 & 24 & 276 \\
\hline $\mathrm{Zn}\left(\mathrm{mg} \mathrm{kg}^{-1}\right)$ & 35 & 24 & 41 & 38 & 34 & 55 \\
\hline $\mathrm{Pb}\left(\mathrm{mg} \mathrm{kg}^{-1}\right)$ & 48 & 31 & 46 & 30 & 35 & 44 \\
\hline $\mathrm{Cd}\left(\mathrm{mg} \mathrm{kg}^{-1}\right)$ & 1.76 & 1.99 & 1.17 & 1.17 & 2.05 & 2.7 \\
\hline $\mathrm{Ni}\left(\mathrm{mg} \mathrm{kg}^{-1}\right)$ & 64 & 53 & 34 & 30 & 53 & 87 \\
\hline $\mathrm{Cr}\left(\mathrm{mg} \mathrm{kg}^{-1}\right)$ & 32 & 25 & 16 & 18 & 30 & 43 \\
\hline
\end{tabular}

* S1: Typic Eutrudept, fine, mixed, subactive, mesic; S2: Dystric Eutrudept, fine-loamy, mixed, superactive, mesic; S3: Dystric Eutrudept, coarseloamy, mixed, superactive, mesic; S4: Dystric Eutrudept, fine-loamy, mixed, superactive, mesic; S5: Vertic Eutrodept, fine-loamy, mixed, superactive, mesic.

\section{MATERIALS AND METHODS}

\subsection{Chemicals, soils and wood ash}

The $p$-Nitrophenylphosphate, $p$-nitrophenylsulphate, $p$-nitrophenol, fluorescein diacetate (3'-6'-diacetyl-fluorescein; FDA), pyrocatechol and L-proline used were from SigmaAldrich Co. All of the other chemicals used were of RPE-ACS analytical grade and were from Carlo Erba (Milan, Italy).

Four soils were from Northern Italy (S1 from Cremona, S2 from Mantova, S3 from the north of Milan, and S4 from the south of Milan) and one from Central Italy (S5 from Ancona). $\mathrm{S} 1$ is a Typic Eutrudept, fine, mixed, subactive, mesic; $\mathrm{S} 2$ is a Dystric Eutrudept, fine-loamy, mixed, superactive, mesic; S3 is a Dystric Eutrudept, coarse-loamy, mixed, superactive, mesic; S4 is a Dystric Eutrudept, fine-loamy, mixed, superactive, mesic and S5 is a Vertic Eutrodept, fine-loamy, mixed, superactive, mesic.

The physical and chemical characteristics of the soils and heavy metal content in the WA were determined according to the ASA-SSSA methods (Klute, 1986; Page, 1982) and are given in Table I. The WA, which came from the combustion of a mixture formed by $80 \%$ pine wood, chestnut wood and beech wood and $20 \%$ buttonwood brush, was sieved at $0.5 \mathrm{~mm}$.

\subsection{Soil sample preparation and experimental plan}

The soils were sampled from the $0-30 \mathrm{~cm}$ soil layer (about $5 \mathrm{~kg}$ of moist soil), air-dried at room temperature, and sieved at $2 \mathrm{~mm}$ to remove plant material, soil macrofauna and stones. After sieving, each soil sample was homogenised for $3 \mathrm{~h}$ in a rotary cylinder and then equilibrated at $60 \%$ of its WHC for 5 days at room temperature under aerobic conditions (Perucci and Scarponi, 1994).

Each soil sample was subdivided into 3 portions $(1 \mathrm{~kg}$ dry weight): one portion was used as control, one was treated with $\mathrm{WA}$ at $5 \mathrm{t} \mathrm{ha}^{-1}$ and one with WA at $20 \mathrm{t} \mathrm{ha}^{-1}$. After homogenisation, the control and treated sub-samples were placed in polypropylene boxes $(12 \times 8 \mathrm{~cm}$ wide, $4 \mathrm{~cm}$ high $)$ with a plastic net on top. In total, for each soil sample, we had 15 boxes each containing $50 \mathrm{~g}$ of control soil, 15 boxes each containing soil treated with WA at $5 \mathrm{tha}^{-1}$ and 15 boxes containing soil treated with WA at $20 \mathrm{t} \mathrm{ha}^{-1}$. Water was added to bring soil moisture to $60 \%$ of the WHC and the samples were stored at $25^{\circ} \mathrm{C}$ in the dark. Soil moisture was controlled weekly and when necessary water was added to the soil to restore the original weights of the sample.

All of the physico-chemical, microbiological and biochemical parameters were evaluated at different times: T0 (start of the incubations, one day after WA addition), and one (T1), two (T2), four (T4), eight (T8) and twelve (T12) months after WA addition.

\subsection{Microbiological and biochemical assays}

Microbial biomass $\mathrm{C}$ and $\mathrm{N}$ were determined by the fumigation-extraction method (Sparling and West, 1988). The hydrolysis rate of FDA was estimated as reported by Schnurer 
Table II. EC $\left(\mu \mathrm{S} \mathrm{cm}^{-1}\right)$ and $\mathrm{pH}$ values in treated and untreated soil samples at the beginning and at the end of the incubation time*.

\begin{tabular}{|c|c|c|c|c|c|c|c|}
\hline \multirow{2}{*}{ Parameter } & \multirow[t]{2}{*}{ Time } & \multirow[t]{2}{*}{ Dose } & \multicolumn{5}{|c|}{ Soil samples } \\
\hline & & & S1 & S2 & S3 & S4 & S5 \\
\hline & & control & $678 \mathrm{a}$ & $815 \mathrm{a}$ & $1045 \mathrm{a}$ & $744 \mathrm{a}$ & $624 \mathrm{a}$ \\
\hline & T0 & $5 \mathrm{t} / \mathrm{ha}$ & $1110 \mathrm{~b}$ & $1232 \mathrm{~b}$ & $1755 \mathrm{~b}$ & $1253 \mathrm{~b}$ & $865 \mathrm{~b}$ \\
\hline & & $20 \mathrm{t} / \mathrm{ha}$ & $1324 \mathrm{c}$ & $1676 \mathrm{c}$ & $1823 \mathrm{~b}$ & $1688 \mathrm{c}$ & $909 \mathrm{~b}$ \\
\hline \multicolumn{8}{|l|}{$\mathrm{EC}$} \\
\hline & & control & $683 \mathrm{a}$ & $807 \mathrm{a}$ & $1010 \mathrm{a}$ & $737 \mathrm{a}$ & $629 a$ \\
\hline & $\mathrm{T} 12$ & $5 \mathrm{t} / \mathrm{ha}$ & $1087 \mathrm{~b}$ & $1141 \mathrm{~b}$ & $1689 \mathrm{~b}$ & $1184 \mathrm{~b}$ & $846 \mathrm{~b}$ \\
\hline & & $20 \mathrm{t} / \mathrm{ha}$ & $1273 \mathrm{c}$ & $1582 \mathrm{c}$ & $1746 \mathrm{~b}$ & $1580 \mathrm{c}$ & $878 \mathrm{~b}$ \\
\hline & & control & $8.1 \mathrm{a}$ & $6.3 \mathrm{a}$ & $6.6 \mathrm{a}$ & $6.7 \mathrm{a}$ & $8.3 \mathrm{a}$ \\
\hline & T0 & $5 \mathrm{t} / \mathrm{ha}$ & $8.4 \mathrm{ab}$ & $7.0 \mathrm{a}$ & $7.1 \mathrm{~b}$ & $7.3 \mathrm{~b}$ & $8.6 \mathrm{ab}$ \\
\hline & & $20 \mathrm{t} / \mathrm{ha}$ & $8.6 \mathrm{~b}$ & $7.9 \mathrm{~b}$ & $7.5 \mathrm{~b}$ & $7.8 \mathrm{c}$ & $8.9 \mathrm{~b}$ \\
\hline \multicolumn{8}{|l|}{$\mathrm{pH}$} \\
\hline & & control & $8.1 \mathrm{a}$ & $6.3 \mathrm{a}$ & $6.6 \mathrm{a}$ & $6.7 \mathrm{a}$ & $8.3 \mathrm{a}$ \\
\hline & $\mathrm{T} 12$ & $5 \mathrm{t} / \mathrm{ha}$ & $8.3 \mathrm{ab}$ & $7.0 \mathrm{a}$ & $7.0 \mathrm{ab}$ & $7.2 \mathrm{~b}$ & $8.4 \mathrm{a}$ \\
\hline & & $20 \mathrm{t} / \mathrm{ha}$ & $8.6 \mathrm{~b}$ & $7.7 \mathrm{~b}$ & $7.3 \mathrm{~b}$ & $7.7 \mathrm{c}$ & $8.8 \mathrm{~b}$ \\
\hline
\end{tabular}

* Values in the same column with different letters are statistically different at $P<0.05$.

and Rosswall (1982) and modified as described by Perucci et al. (2000a). Alkaline phosphatase (AlkPase, EC 3.1.3.1) and arylsulphatase (ArSase, EC 3.1.6.1) activities were measured according to Tabatabai (1982); catalase activity (CATase, EC 1.11.1.6) was measured by the Roberge method (1978) with slight modifications (Perucci et al., 1997) and orto-diphenoloxidase activity ( $o$-DPO, EC 1.10.3.1) was evaluated as described by Perucci et al. (2000b).

\subsection{Statistical analysis}

The enzyme activities were analysed by a three-way factorial, applying the Model I of analysis of variance (Sokal and Rholf, 1969) and considering the following variables: A, soil (type); B, dose (WA rate) and $\mathrm{C}$, incubation time (0, 1, 2, 4, 8 and 12 months). All of the data are the mean of three replicates, and each replication is the mean of two determinations. The data reported in the tables were analysed statistically according to Duncan's multiple range test. Pooled standard errors of the differences (s.e.d) for the time $\times$ dose interaction were calculated separately for each soil and are reported in Figures 1-6.

\section{RESULTS AND DISCUSSION}

The electrical conductivity (EC) and $\mathrm{pH}$ values measured in control and treated soils at T0 and T12 are reported in Table II.

Significant increases in EC values were found at both WA doses for all soil samples. As seen by Clapham and Zibilske (1992), the EC showed an initial increase (more pronounced at the higher WA rate), followed by a slight decrease. However, at the end of the incubations the final values were always significantly higher than values of the respective controls, at both WA doses, and the increases observed could be due to the amounts of soluble salts added.

The WA addition at the highest rate significantly increased $\mathrm{pH}$. Ohno (1992) found that the increases were higher in soils with a lower initial $\mathrm{pH}$ value under laboratory conditions. During the incubation, no significant changes in $\mathrm{pH}$ were observed, and thus at the end of the incubations, the $\mathrm{pH}$ values remained the same as their respective controls.

\subsection{Microbiological parameters}

Increases in microbial biomass $\mathrm{C}$ content (MBC, Fig. 1) were generally observed during the first 4 months of incubation. However, at the end of the incubation period the MBC was lower in the S4 and S5 samples than in the control, while a recovery of the $\mathrm{MBC}$ was observed for the $\mathrm{S} 3$ sample.

The MBC increases following the treatments at $5 \mathrm{t} \mathrm{ha}^{-1}$ could be due to the fine granulometry of the WA, a structure that permits a weak and quick increase in $\mathrm{pH}$ and a prompt supply of nutrients. Indeed, the major availability of nutrients and the small increase in $\mathrm{pH}$ stimulated the microbial growth and probably, as reported in the literature, the growth of heavy metalresistant bacteria (Gaad, 1992; Killman, 1994; Bååth et al., 1995). In contrast, the MBC decreases observed for the $20 \mathrm{tha}^{-1}$ treatment can be explained by the toxic effects of the heavy metals with partial death of soil microflora. In fact, microorganisms differ in their sensitivities to metal toxicity, and metal exposure 
s1

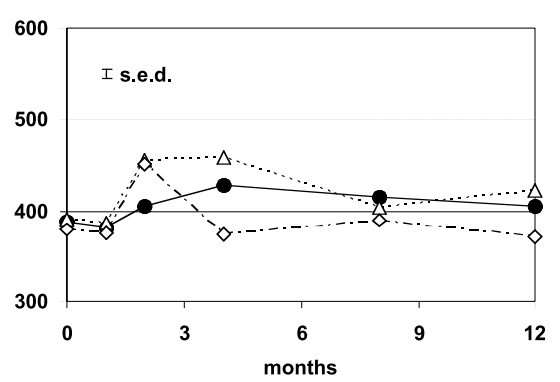

S4

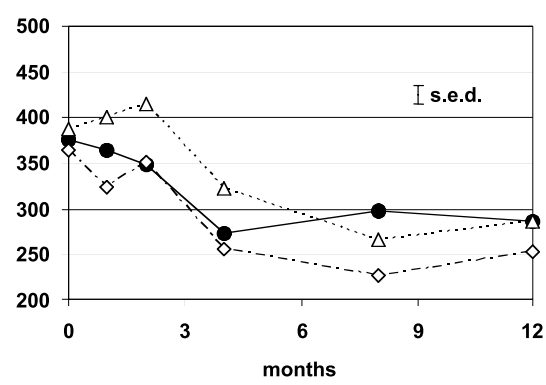

S2
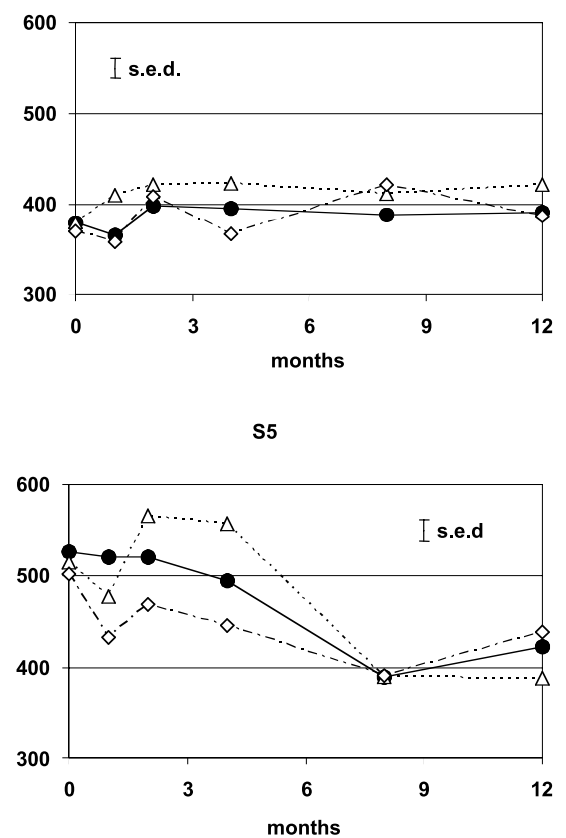

S3

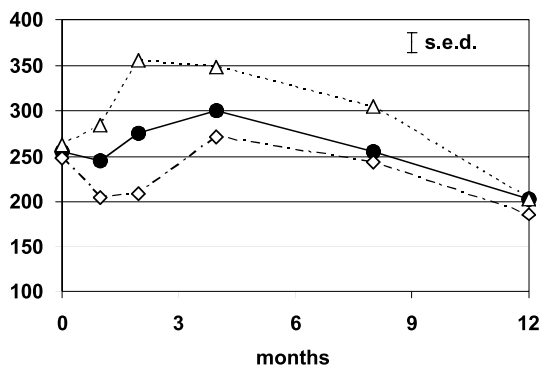

Figure 1. Microbial biomass $\mathrm{C}$ content $\left(\mathrm{mg} \mathrm{C} \mathrm{kg}^{-1}\right)$ in treated and untreated soil samples at different incubation times.

can result either in the immediate death of some cells due to the disruption of their essential functions, or in changes in population sizes and structure (Giller et al., 1998). Another possibility is that the strong and significant increases in EC can induce osmotic phenomena in all living microorganisms, with increases in respiration and decreases in microbial biomass.

In addition, changes in size and structure of the microbial communities occurred at the higher WA dose. This hypothesis is supported by the study of Bååth et al. (1995), who showed that high rates of WA significantly reduced microbial biomass, and that the fungi were more seriously affected than the bacteria in coniferous forest soils.

Our findings also agree with those of Vance (1996) and Chander et al. (2001). The former found that the changes in MBC were correlated with the granulometry of the WA added to soil, and that the addition of fine WA granulometry immediately affected the system. These effects disappeared or decreased with time. The latter study demonstrated that the heavy metals of WA can have detrimental effects on the nutrient uptake by microbial cells over long periods of time.

The effects of WA addition were more evident by considering the microbial $\mathrm{C} / \mathrm{N}$ ratios (Tab. III). Both WA rates significantly changed the $\mathrm{C} / \mathrm{N}$ ratios with respect to the values of their respective controls (generally more evident for the higher WA rate). Perkiomaki and Fritze (2002) observed changes in microbial activity and community structure of coniferous forest soils, and that these were related to the dose and the form of the WA applied.

Perucci (1992) reported a close relationship between the rate of hydrolysis of FDA (FDA hydrolysis) and soil microbial biomass. Subsequently, Dumontet et al. (1997) and Adam and Duncan (2001) suggested that FDA hydrolysis is a simple, rapid and sensitive method for measuring the total microbial activity in a wide range of soils.

Increases in FDA hydrolysis were observed in all treated soils during the T1-T2 incubation period, and generally they were highest at the lower WA rate (Fig. 2). In contrast, during the subsequent T4-T12 incubation period, FDA hydrolysis decreased at both WA addition rates, with higher decreases generally at the higher dose.

The initial increases observed at the lower WA addition rate could be related to the increase in MBC stimulated by the higher amounts of available nutrients, as discussed above. The small increases in FDA hydrolysis in the $20 \mathrm{tha}^{-1}$ treatment are probably due to the predominance of bacteria over fungi that cannot survive at the high $\mathrm{pH}$ values. The later decreases with both treatments could be related to the decrease in the amount of available nutrients consumed by the microbial growth of the first period of incubation.

\subsection{Enzyme activities}

The WA additions were performed under laboratory conditions to evaluate their effects on soil biochemical parameters without any environmental interference. The changes in microbiological and biochemical parameters in the soils with incubation time are reported in Figures 3-6.

As shown in Table I, WA contains moderate amounts of $\mathrm{P}$ (WA phosphorus), which are mainly present as orthophosphate. It is well established that phosphatase activity depends on available P (Perucci, 1992; Nannipieri, 1994; Juma and Tabatabai, 1997). 
s1

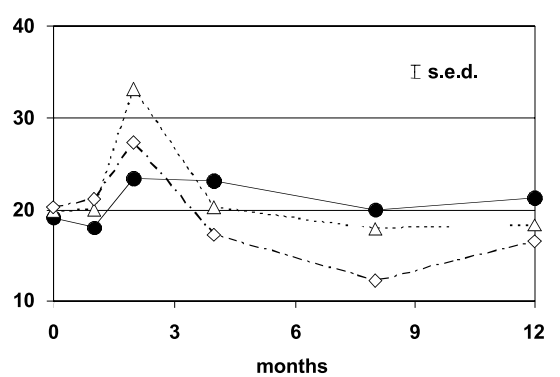

S4

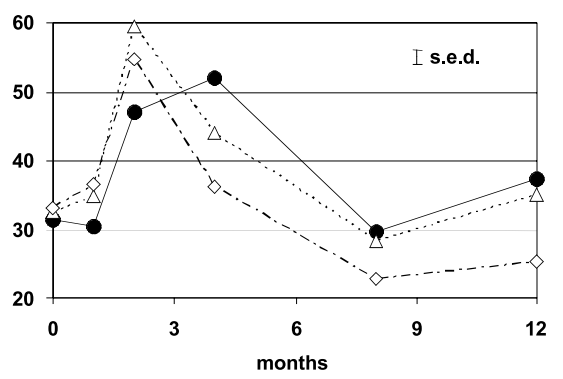



S5

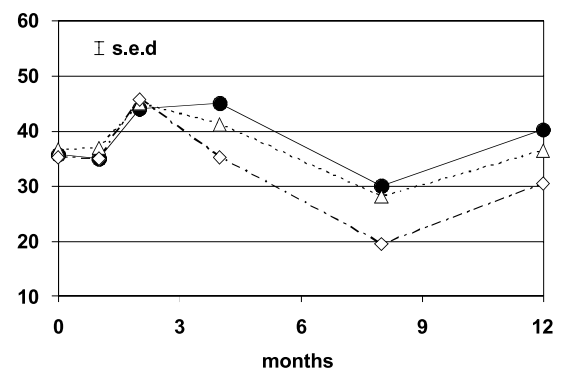

\$3

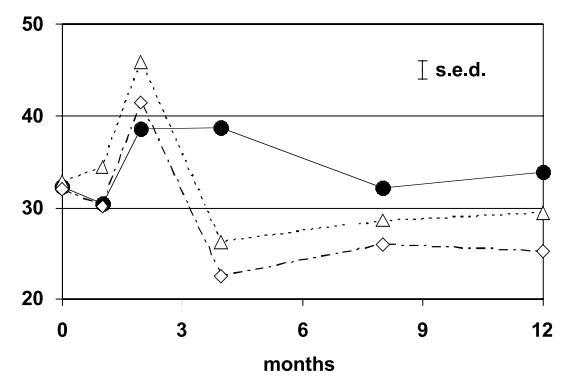

Figure 2. Rate of FDA hydrolysis ( $\mu \mathrm{g}$ of hydrolysed FDA $\mathrm{g}^{-1} \mathrm{~h}^{-1}$ ) in treated and untreated soil samples at different incubation times.

Table III. C/N values in treated and untreated soil samples at different incubation times*.

\begin{tabular}{|c|c|c|c|c|c|c|}
\hline \multirow[t]{2}{*}{ Time } & \multirow[t]{2}{*}{ Dose } & \multicolumn{5}{|c|}{ Soil samples } \\
\hline & & S1 & S2 & S3 & S4 & S5 \\
\hline \multirow[t]{2}{*}{ T0 } & & 6.9 & 14.5 & 14.9 & 14.7 & 12.0 \\
\hline & control & $6.7 \mathrm{a}$ & $14.6 \mathrm{~b}$ & $15.3 b$ & $14.6 \mathrm{~b}$ & $11.6 \mathrm{a}$ \\
\hline \multirow[t]{3}{*}{$\mathrm{T} 1$} & $5 \mathrm{t} / \mathrm{ha}$ & $6.1 \mathrm{a}$ & $9.3 \mathrm{a}$ & $10.1 \mathrm{a}$ & $9.8 \mathrm{a}$ & $9.9 \mathrm{a}$ \\
\hline & $20 \mathrm{t} / \mathrm{ha}$ & $7.2 \mathrm{a}$ & $8.3 \mathrm{a}$ & $10.8 \mathrm{a}$ & $8.5 \mathrm{a}$ & $10.7 \mathrm{a}$ \\
\hline & control & $6.3 \mathrm{a}$ & $14.2 \mathrm{~b}$ & $15.3 \mathrm{~b}$ & $13.4 \mathrm{c}$ & $16.8 \mathrm{~b}$ \\
\hline \multirow[t]{3}{*}{$\mathrm{T} 4$} & $5 \mathrm{t} / \mathrm{ha}$ & $6.8 \mathrm{a}$ & $10.8 \mathrm{a}$ & $13.9 \mathrm{~b}$ & $11.8 \mathrm{~b}$ & $16.7 \mathrm{~b}$ \\
\hline & $20 \mathrm{t} / \mathrm{ha}$ & $7.1 \mathrm{a}$ & $10.5 \mathrm{a}$ & $7.2 \mathrm{a}$ & $9.5 \mathrm{a}$ & $14.7 \mathrm{a}$ \\
\hline & control & $9.6 \mathrm{a}$ & $19.8 \mathrm{~b}$ & $17.7 \mathrm{c}$ & $14.4 \mathrm{c}$ & $11.8 \mathrm{a}$ \\
\hline \multirow[t]{3}{*}{$\mathrm{T} 8$} & $5 \mathrm{t} / \mathrm{ha}$ & $8.8 \mathrm{a}$ & $11.8 \mathrm{a}$ & $14.4 \mathrm{~b}$ & $12.8 \mathrm{~b}$ & $11.8 \mathrm{a}$ \\
\hline & $20 \mathrm{t} / \mathrm{ha}$ & $11.6 \mathrm{~b}$ & $10.2 \mathrm{a}$ & $11.9 \mathrm{a}$ & $11.7 \mathrm{a}$ & $13.5 \mathrm{a}$ \\
\hline & control & $8.6 \mathrm{a}$ & $20.1 \mathrm{~b}$ & $10.7 \mathrm{~b}$ & $12.0 \mathrm{~b}$ & $10.4 \mathrm{a}$ \\
\hline \multirow[t]{2}{*}{$\mathrm{T} 12$} & $5 \mathrm{t} / \mathrm{ha}$ & $8.0 \mathrm{a}$ & $12.1 \mathrm{a}$ & $10.2 \mathrm{~b}$ & $10.6 \mathrm{~b}$ & $9.7 \mathrm{a}$ \\
\hline & $20 \mathrm{t} / \mathrm{ha}$ & $10.9 \mathrm{~b}$ & $11.7 \mathrm{a}$ & $8.8 \mathrm{a}$ & $8.9 \mathrm{a}$ & $9.2 \mathrm{a}$ \\
\hline
\end{tabular}

* Values in the same column and at the same time followed by different letters are statistically different at $P<0.05$.

WA addition increases alkaline phosphatase activity (Fig. 3), probably because soil $\mathrm{pH}$ was increased and available $\mathrm{P}$ decreased due to its fixation and/or precipitation. This process affects the phosphatase activity, according to Perucci and Scarponi (1985). Our findings also agree with Erich and Ohno (1992), who reported that WA P is only very weakly soluble 
s1

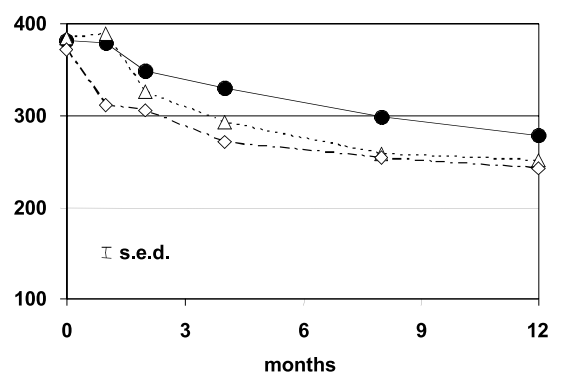

S4

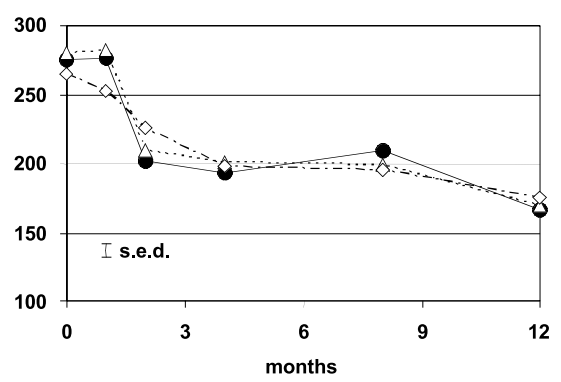

S2

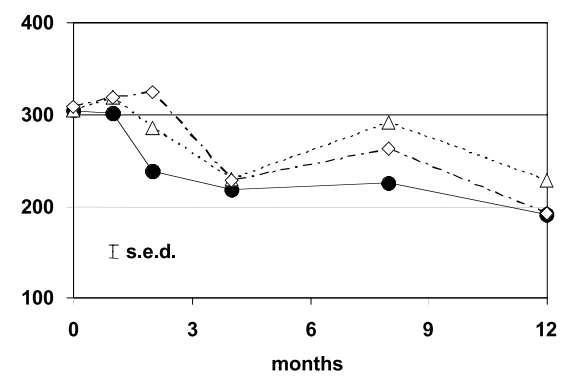

S5

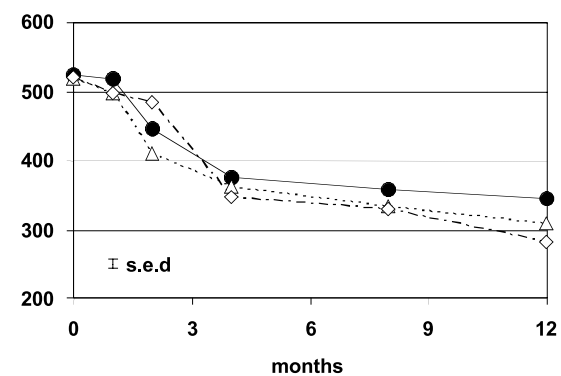

S3


Figure 3. Alkaline phosphatase activity ( $\mu \mathrm{g} p$-Nitrophenol $\mathrm{g}^{-1} \mathrm{~h}^{-1}$ ) in treated and untreated soil samples at different incubation times.

and a large portion of the dissolved phosphorus becomes immobilised in the soil with an increase in $\mathrm{pH}$.

No effects were observed in the $\mathrm{S} 4$ soil (Fig. 3). In contrast, in the $\mathrm{S} 1$ and $\mathrm{S} 5$ soils, which have the highest $\mathrm{pH}$ values, there was a significant inhibition of the alkaline phosphatase activity at the highest WA rate. We are not able to explain these results because extracellular alkaline phosphatases are able to operate in alkaline environments, and thus were unaffected by the small $\mathrm{pH}$ changes. Furthermore, by increasing $\mathrm{pH}$, both the phosphate and heavy metal contents of the soil solution decrease, and therefore these parameters cannot be responsible for the observed behaviour.

Soil arylsulphatases are the enzymes responsible for sulphur mineralisation, and they represent an important and indirect index of the presence of fungi, which are the only soil microorganisms containing ester sulphates (Bandick and Dick, 1999; Klose and Tabatabai, 1999). Arylsulphatase activities are sensitive to both sulphate and phosphate concentrations in soil solutions (Alef and Nannipieri, 1995). However, during the combustion of the wood the organic sulphur is lost through volatilisation, and consequently any change in the enzyme activity can be attributed to the phosphate concentration and/or to the heavy metals added, upon which the fungi/bacteria ratio depends (Giller et al., 1998). At both WA rates, significant arylsulphatase changes were found in a few cases (Fig. 4) even though the increases observed at $\mathrm{T} 1$ could be attributed to an increase in the free sulphatases arising in the soil after the death of the fungi due to the toxic effects of the WA addition.

Catalases are intracellular enzymes that are present in all aerobic bacteria and most facultative anaerobes, but that are absent from obligate anaerobes (Alef and Nannipieri, 1995). Catalase activity in the soil is considered an indicator of aerobic microbial activity and has been related to both the number of the aerobic microorganisms and the soil fertility (Garcia and Hernandez, 1997).

The effects of the WA addition on the amount of catalaseproducing microorganisms, which depends on the type of soil, are shown in Figure 5. Significant increases, depending on WA dose, were found in the S2, S3 and S4 samples, while significant decreases in S1 and S5 were observed.

The increases in catalase activity could be related to a greater presence of oxygen, since the $\mathrm{S} 2, \mathrm{~S} 3$ and $\mathrm{S} 4$ samples are characterised by high levels of sand, and consequently a high degree of microporosity. The lower activities, observed in the S1 and S5 samples at both WA rates, could be attributed to the fine granulometry of the WA, which would have decreased the microporosity in the soils characterised by a major clay content.

Another important group of intracellular enzymes is represented by the $o$-diphenoloxidases (o-DPO), which once excreted by microorganisms, such as the fungi Aspergillus, Penicillium and Trichoderma and actinomycetes (Claus and Filip, 1990) and the bacteria Bacillus, Arthrobacter and Pseudomonas (Dec et al., 2002) act on fresh organic matter, initiating the humification process.

Increases in $o$-diphenoloxidase activity, correlated with the WA addition rate, were observed, highlighting the role of the WA rate in determining the level of this effect over time (Fig. 6).

Perucci et al. (2000b) reported on the mechanisms of $o$-DPO activity, where they indicated the importance of the alkaline $\mathrm{pH}$. Therefore, the behaviour observed in all of the WA-treated samples indicated a moderate increase in the humification capacity. These findings agree with the hypothesis that as the treated soils had a greater availability of nutrients with respect 
s1

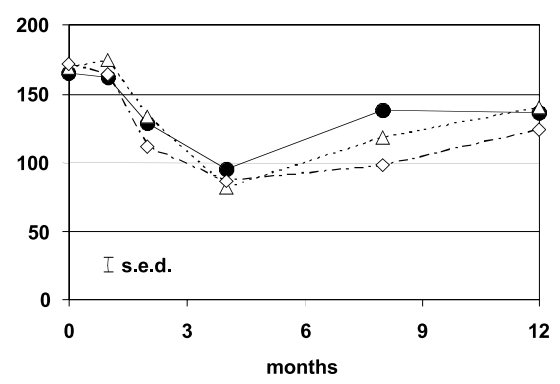

S4

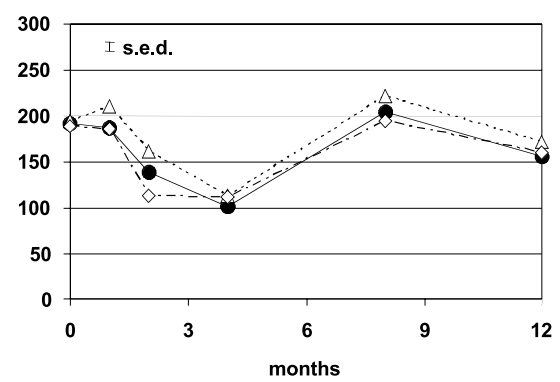

S2

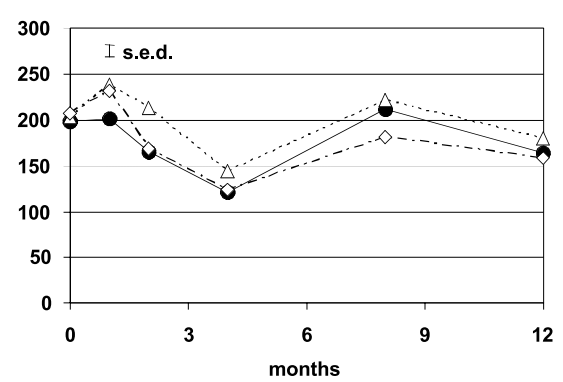

S5

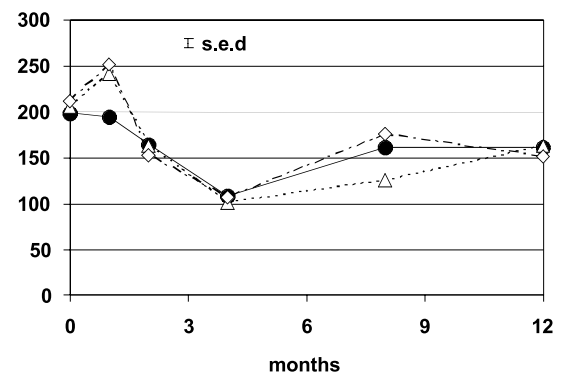

S3

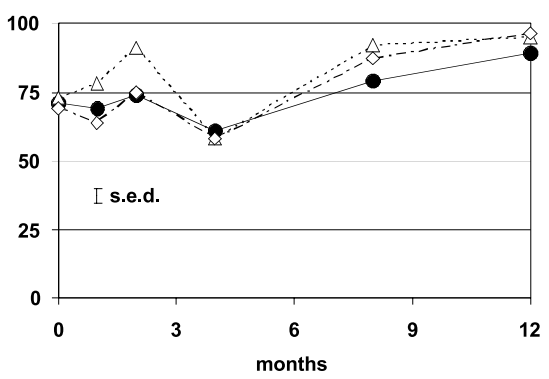

Figure 4. Arylsulphatase activity ( $\mu \mathrm{g}$ of $p$-Nitrophenol $\mathrm{g}^{-1} \mathrm{~h}^{-1}$ ) in treated and untreated soil samples at different incubation times.

s

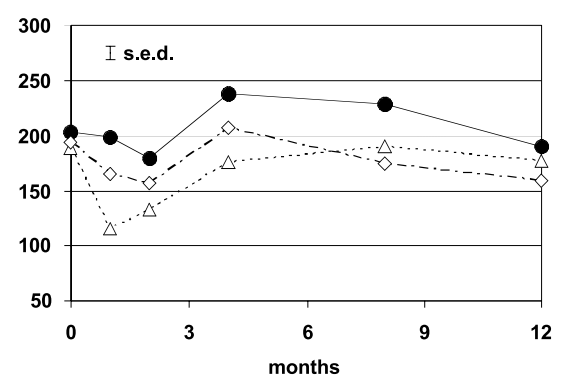

S4

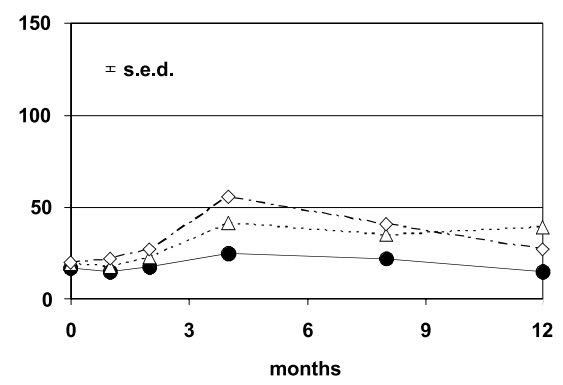

S2

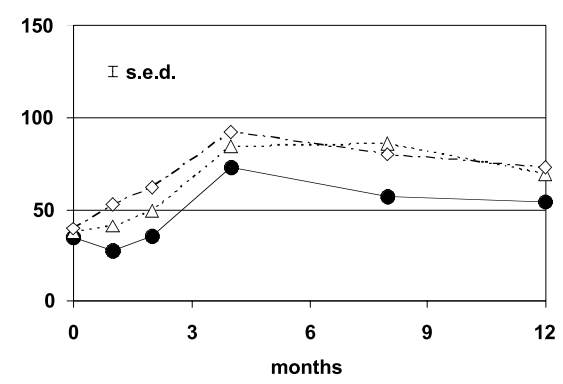

S5

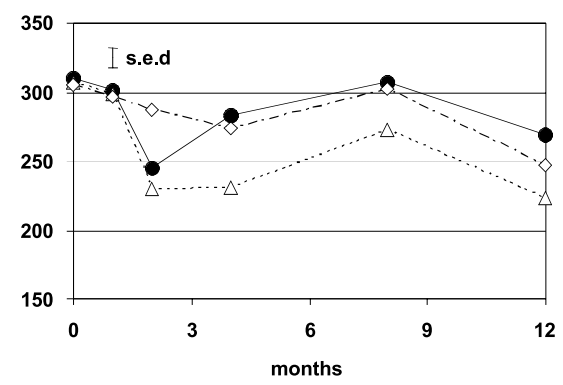

S3
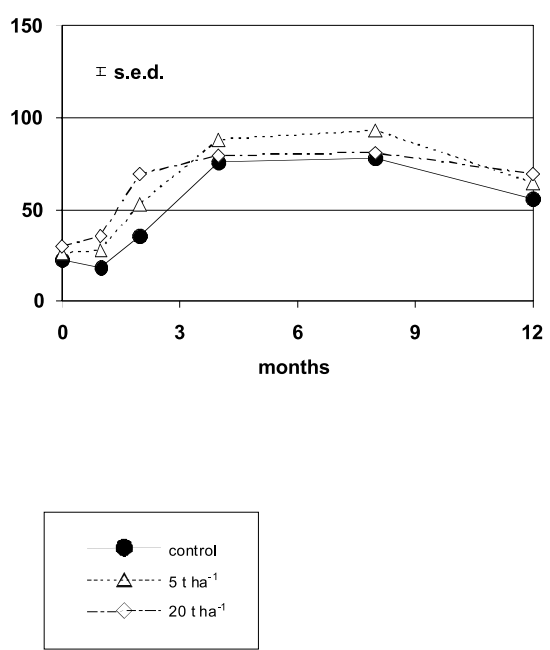

Figure 5. Catalase activity $\left(\mathrm{mg} \mathrm{O}_{2} \mathrm{~g}^{-1}\right)$ in treated and untreated soil samples at different incubation times.

to their controls, the microorganisms had no need to mineralise organic matter; in contrast, the humification process of native organic matter became more significant. This is also supported by the EC determinations: the decreases in the EC from T0 to
T12 are probably due to the lack of mobility of nutrients, since leaching is not possible under these conditions. In this way, many nutrients can be immobilised in the organic matter, forming a reserve for the growth of crops. 
s1

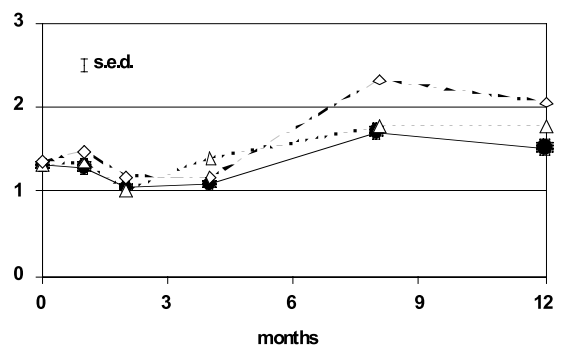

s4

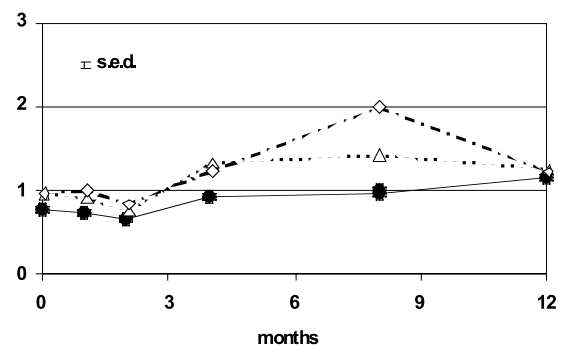

s2

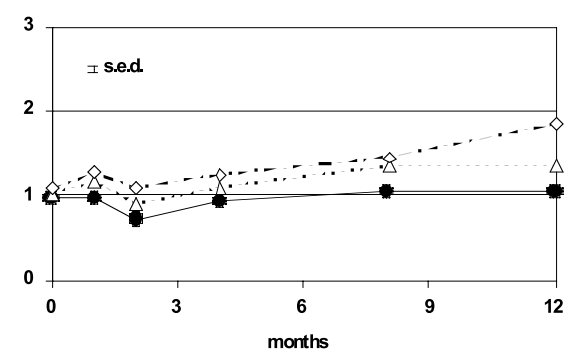

S5

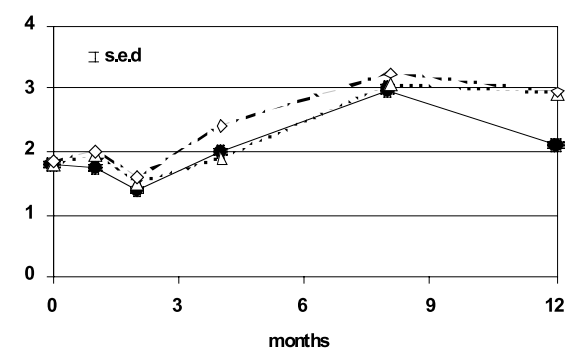

s3

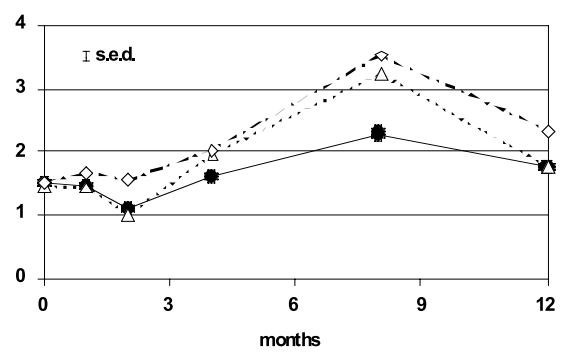

Figure 6. $o$-Diphenoloxidase activity ( $\mu$ moles of oxidised catechol $\mathrm{g}^{-1} 10 \mathrm{~min}^{-1}$ ) in treated and untreated soil samples at different incubation times.

Table IV. Analysis of variance.

\begin{tabular}{|c|c|c|c|c|c|c|c|}
\hline Source of variation & df & Biomass C & FDA & AMPase & $\begin{array}{c}\mathrm{Fs}^{\mathrm{a}} \\
\text { ArSase }\end{array}$ & CATase & o-DPO \\
\hline A. & 4 & $523.99 * *$ & $436.39 * *$ & & $677.60 * *$ & $4956.29 * *$ & $496.67 * *$ \\
\hline Soil & & & & $2300.16^{* *}$ & & & \\
\hline B. & 5 & $38.84 * *$ & $232.48 * *$ & & $233.37 * *$ & $60.59 * *$ & $276.96 * *$ \\
\hline Time & & & & $468.01 * *$ & & & \\
\hline C. & 2 & $62.45 * *$ & $69.71 * *$ & & $18.51 * *$ & $16.97 * *$ & $133.63 * *$ \\
\hline Rate & & & & $9.86 * *$ & & & \\
\hline $\mathrm{A} \times \mathrm{B}$ & 20 & $14.65 * *$ & $13.81 * *$ & & $25.18 * *$ & $25.51 * *$ & $21.04 * *$ \\
\hline Soil $\times$ Time & & & & $44.30 * *$ & & & \\
\hline $\mathrm{A} \times \mathrm{C}$ & 8 & 1.55 & $2.55^{*}$ & & $6.24 * *$ & $28.55 * *$ & 1.71 \\
\hline Soil $\times$ Rate & & & & $23.38 * *$ & & & \\
\hline $\mathrm{B} \times \mathrm{C}$ & 10 & $4.56 * *$ & $28.85 * *$ & & $5.37 * *$ & $3.86 * *$ & $8.56^{* *}$ \\
\hline Time $\times$ Rate & & & & $8.00 * *$ & & & \\
\hline $\mathrm{A} \times \mathrm{B} \times \mathrm{C}$ & 40 & $1.78 * *$ & $2.41 * *$ & & $2.07 * *$ & $3.00 * *$ & $3.21 * *$ \\
\hline Soil $\times$ Time $\times$ Rate & & & & $3.25 * *$ & & & \\
\hline Error (Mean Square) & 180 & 682.00 & 6.44 & 201.16 & 149.06 & 123.49 & 0.02 \\
\hline
\end{tabular}

${ }^{\mathrm{a}} \mathrm{F}$ tests followed by $*$ or $* *$ are significant at a probability level lower than $P=0.05(*)$ or $P=0.01(* *)$.

Finally, the analysis of variance of MBC, FDA and the enzyme activities shows that the WA additions caused significant effects on all of the tested parameters relating to soil types (A), time of incubation (B) and rate (C) (Tab. IV). In particular, with the exception of MBC and $o$-DPO, the changes in CATase, ArSase, AMPase and FDA were significantly influenced by the rates (as demonstrated by the $\mathrm{A} \times \mathrm{C}$ interactions). Furthermore, the time $\times$ dose interaction $(B \times C)$ and the soil $x$ time interaction $(\mathrm{A} \times \mathrm{B})$ indicate that the WA had different effects on the enzyme activities over time.
The effects of WA addition were dependent on incubation time, dose and soil, and these three factors significantly interacted with one another (Tab. IV).

\section{CONCLUSIONS}

The application of WA to agricultural soils can primarily provide an efficient way for its disposal and it could also be of particular interest for the recycling of the exported nutrients. Our findings suggest that, even if the addition of WA in agricultural soils could have a generally toxic effect on the soil 
microorganisms, this effect is generally short-lived and it depends on the WA rate, soil structure and time. In conclusion, the application of WA does not present any risks for the environment, provided that excessive amounts are not applied. Indeed, our findings reveal that the biochemical parameters are significantly affected in only some cases at $20 \mathrm{t} \mathrm{ha}^{-1}$, suggesting that a treatment at $5 \mathrm{tha}^{-1}$ can be used as an annual sequence for the soils in Italy.

Acknowledgements: The authors would like to thank the Regione Lombardia and CTI (Italian Thermotechnic Committee) for financial support. They would also like to thank Dr Andrea Onofri of the Department of Agricultural and Environmental Sciences of Perugia University for his assistance with the statistical analysis, and Barbara Gonnella and Alessandra Cardinali for their useful help with the experiment management.

\section{REFERENCES}

Adam G., Duncan H. (2001) Development of a sensitive and rapid method for the measurement of total microbial activity using fluorescein diacetate (FDA) in a range of soils, Soil Biol. Biochem. 33, 943-951.

Alef K., Nannipieri P. (1995) Enzyme activities, in: Alef K., Nannipieri P. (Eds.), Methods in applied Soil Microbiology and Biochemistry, Academic Press, London, pp. 311-373.

Bååth E., Frostegård A., Pennanen T., Fritze E. (1995) Microbial community structure and $\mathrm{pH}$ response in relation to soil organic matter quality in wood-ash fertilized, clear-cut or burned coniferous forest soils, Soil Biol. Biochem. 27, 229-240.

Bandick R., Dick W.R. (1999) Field management effects on soil enzyme activities, Soil Biol. Biochem. 31, 1471-1479.

Berg N., Ekbohm G., Soderstrom B.E., Staaf H. (1991) Reduction of decomposition rates of Scots pine needle litter due to heavy metal pollution, Water Air Soil Poll. 59, 165-178.

Buttner G., Gering C., Nell U., Rumpf S.V., Wilpert K. (1998) K insatz von holzasche in waldern (Wood ash application in forests), Forst Holtz 53, 72-76.

Chander K., Dyckmans J., Joergensen R.G., Meyer B., Raubuch M. (2001) Different sources of heavy metals and their long-term effects on soil microbial properties, Biol. Fert. Soils 343, 241-247.

Clapham W.M., Zibilske L.M. (1992) Wood ash as a liming amendment, Commun. Soil Sci. Plant 23, 1209-1227.

Claus H., Filip Z. (1990) Effects of clays and other solids on the activity of phenoloxidase produced by fungi and actinomycetes, Soil Biol. Biochem. 22, 483-488.

Cronan C.S., Grical D.F. (1995) Use of calcium/aluminium ratios as indicators of stress in forest ecosystems, J. Environ. Qual. 24, 209-226.

Dec J., Bollag J.M., Huang P.M., Senesi N. (2002) Impact of interactions between microorganisms and soil colloids on the transformation of organic pollutants, in: Huang P.M., Bollag J.M., Senesi N. (Eds.), Interactions between soil particles and microorganisms: Impact on the terrestrial ecosystem, John Wiley and Sons, LTD, pp. 323-378.

Demeyer A., Voundi Nkana J.C., Verloo M.G. (2001) Characteristics of wood ash and influence on soil properties and nutrient uptake: an overview, Bioresourse Technol. 77, 287-295.

Dumontet S., Perucci P., Bufo S.A. (1997) Les amendements organiques et traitements avec les herbicides. Influence sur la biomasse microbienne du sol, Prooceding du XXVII Congres du Groupe Français des Pesticides, Orléans (France), p. 211.

Erich M.S., Ohno T. (1992) Phosphorous availability to corn from wood ash amended soils, Water, Air Soil Poll. 64, 475-485.

Gadd G.M. (1992) Metals and microorganism: a problem of definition, Fems Microbiol. Lett. 100, 197-203.

Garcia C., Hernandez T. (1997) Biological and biochemical indicators in derelict soils subject to erosion, Soil Biol. Biochem. 29,171-177.

Giller K.E., Witter E., McGrath S.P. (1998) Toxicity of heavy metals to microorganisms and microbial processes in agricultural soils: a review, Soil Biol. Biochem. 30, 1389-1414.
Juma N.G., Tabatabai M.A. (1997) Effects of trace elements on phosphatase activity in soils, Soil Sci. Soc. Am. J. 41, 343-346.

Killman K. (1994) Soil Ecology, Cambridge University Press, Cambridge.

Klose D.J., Tabatabai M.A. (1999) Arylsulphatase activity of microbial biomass, Soil Sci. Soc. Am. J. 63, 569-574.

Klute A. (1986) Methods of soil analysis: physical and mineralogical methods, in: Page A.L., Miller R.H., Keeney D.R. (Eds.), Methods in soil analysis. Part 1. 2nd ed., Agronomy Monograph No. 9, ASA and SSSA, Madison, Wi.

Nannipieri P. (1994) The potential use of soil enzymes as indicators of productivity, sustainability and pollution, in: Pankhurst C.E., Doube B.M., Gupta V.V.S.R., Grace P.R. (Eds.), Soil Biota. management in sustainable farming system, CSIRO, Australia, pp. 238-244.

Ohno T. (1992) Neutralization of soil acidity and release of phosphorus and K by wood ash, J. Environ. Qual. 21,433-438.

Page A.L. (1982) Methods in soil analysis: chemical and microbiological properties, in: Page A.L., Miller R.H., Keeney D.R. (Eds.), Methods in soil analysis. Part 2. Agronomy Monograph No. 9, ASA and SSSA, Madison, Wi.

Perkiomaki J., Fritze H. (2002) Short and long-term effects of wood ash on the boreal forest humus microbial community, Soil Biol. Biochem. 34,1343-1353.

Perucci P. (1992) Enzyme activity and microbial biomass in a field soil amended with municipal refuse, Biol. Fert. Soils 14, 54-60.

Perucci P., Scarponi L. (1985) Effect of different treatments with crop residues on soil phosphatase activities, Biol. Fert. Soils 1, 111-115.

Perucci P., Scarponi L. (1994) Effects of the herbicide imazethapyr on soil microbial biomass and various soil enzyme activities, Biol. Fert. Soils 17, 237-240.

Perucci P., Bonciarelli U., Santilocchi R., Bianchi A.A. (1997) Effect of rotation, nitrogen fertilization and management of crop residues on some chemical, microbiological and biochemical properties of soil, Biol. Fert. Soils 24, 311-316.

Perucci P., Dumontet S., Bufo S.A., Mazzatura A., Casucci C. (2000a) Effect of organic amendment and herbicide treatment on soil microbial biomass, Biol. Fert. Soils 32,17-23.

Perucci P., Casucci C., Dumontet S. (2000b) An improved method to evaluate in situ the $o$-diphenoloxidase activity in soil, Soil Biol. Biochem. 32, 1927-1933.

Roberge M.R. (1978) Methodology of enzyme measurement and extraction. Appendix on soil enzymes, in: Burns R.G. (Ed.), Soil enzymes, Academic Press, London, pp. 341-370.

Schnurer J., Rosswall T. (1982) Fluorescein diacetate hydrolysis as a measure of total microbial activity in soil and in litter, Appl. Environ. Microbiol. 43, 1256-1261.

Sokal R.R., Rholf J.F. (1969) Multiway analysis of variance, in: Emerson R., Kennedy D., Park R.B. (Eds.), Biometry, The principles and pratice of statistics in biological research, Freeman, San Francisco, CA, pp. 343-366.

Sparling G.P., West A.W. (1988) Modifications to the fumigation-extraction technique to permit simultaneous extraction and estimation of soil microbial C and N, Commun. Soil Plant Anal. 19, 327-344.

Tabatabai M.A. (1982) Soil enzymes, in: Page A.L., Miller R.H., Keeney D.R. (Eds.), Methods in soil analysis. Part 2. Agronomy Monograph No. 9, ASA and SSSA, Madison, Wi, 1982, pp. 903-947.

Vance E.D. (1996) Land application of wood-fired and combination boiler ashes: an overview, J. Environ. Qual. 25, 937-944.

Vance E.D., Mitchell C.C. (2000) Beneficial use of wood ash as an agricultural soil amendment: case studies from the United States forest products industry, in: Power J.F., Dick W.A. (Eds.), Land application of agricultural, Industrial and Municipal By-Products, SSSA, Madison, Wi, 2000, pp. 567-582.

Zimmermann S., Frey B. (2002) Soil respiration and microbial properties in an acid forest soil: effects of wood ash, Soil Biol. Biochem. 34, 1727-1737. 